\title{
MEMAHAMI PELANGGARAN HUKUM DAN KONSEKUENSINYA TERKAIT DENGAN PENYALAHGUNAAN NARKOTIKA BAGI SISWA SMAS KATOLIK YOS SUDARSO
}

\author{
Ade Adhari, Glen Clifford Mambo Jr dan Grace Bernadette Michelle \\ Fakultas Hukum, Universitas Tarumanagara, Jakarta \\ Surel: adea@fh.untar.ac.id
}

\begin{abstract}
There are various kinds of law violations committed by high school students, and one of them is using narcotics. Drug abuse is a serious problem faced by high school students in Indonesia. The survey also explains that the main reason for high school students to use drugs is to experiment or be curious. This is a serious problem because drugs have a negative impact on the lives of high school students and can damage their future. Drug abuse has an impact on every aspect of student life, both psychologically, healthily, and socially. The solution to dealing with drug abuse is to increase students' understanding through legal counseling. The method of implementing community service activities this time is the lecture method. The material presented relates to various violations of the law and narcotics. This activity was held at Yos Sudarso High School. The result of this outreach activity is an increase in understanding of the law, the purpose of the law, violations of the law, the consequences of violating the law and the dangers of narcotics for adolescents.
\end{abstract}

Keywords: Violation of the Law, Narcotics

ABSTRAK

Pelanggaran hukum yang dilakukan oleh anak SMA beraneka ragam, dan salah satunya menggunakan narkotika. Penyalahgunaan narkoba merupakan masalah serius yang dihadapi oleh anak SMA di Indonesia. Survei juga menjelaskan alasan utama penggunaan narkoba pada anak SMA adalah ingin mencoba-coba atau penasaran. Ini adalah masalah serius dikarenakan narkoba berdampak negatif bagi kehidupan anak SMA dan dapat merusak masa depan mereka. Penyalahgunaan narkoba berdampak di setiap aspek kehidupan siswa, baik terhadap psikis, kesehatan, dan sosialnya. Solusi untuk menghadapi penyalahgunaan narkoba yaitu dengan meningkatkan pemahaman siswa melalui penyuluhan hukum. Metode pelaksanaan kegiatan pengabdian kepada masyarakat kali ini adalah metode ceramah. Materi yang disampaikan berkenaan dengan berbagai pelanggaran hukum dan narkotika. Kegiatan ini diadakan di SMA Yos Sudarso. Hasil dari kegiatan penyuluhan ini adalah peningkatan pemahaman mengenai hukum, tujuan hukum, pelanggaran hukum, konsekuensi pelanggaran hukum dan bahaya narkotika bagi remaja.

Kata Kunci: Pelangaran Hukum, Narkotika

\section{PENDAHULUAN}

SMAK Yos Sudarso merupakan sekolah swasta khatolik yang dikelola Yayasan Tunas karya. Apabila melihat sejarah pembentukan dari sekolah tersebut, SMAK Yos Sudarso termasuk salah satu sekolah tertua di Batam. Sekolah ini dibangun pada tahun 1970-an di Batam. Kedisiplinan, nilai etika dan moral merupakan karakteristik yang ditanamkan di SMA Yos Sudarso. Karekteristik tersebut dijalankan oleh para guru, karyawan dan para siswa. Hal ini berimplikasi pada tingkat kepatuhan terhadap aturan yang berlaku. Untuk mempertahankan perilaku taat hukum, SMAK Yos Sudarso meminta Universitas Tarumanagara untuk memberikan pemahaman tentang pelanggaran hukum dan konsekuensinya.

Pelanggaran hukum merupakan masalah besar di Indonesia. Oleh sebab itu SMAKK Yos Sudarso memandang perlu mencegah terjadinya berbagai pelanggaran hukum oleh para siswa. Salah satu bentuk pelanggaran hukum yang diperlukan penjelasannya adalah penyalahgunaan narkotika. Menurut data survei data BNN, anak SMA yang memakai narkoba dalam 1 (satu) tahun terakhir ini sebanyak 47,7\% anak SMA pernah memakai narkoba dan 57,4\% anak SMA yang dalam 1 tahun terakhir memakai narkoba (LIPI, 2019). SMAS Yos Sudarso berharap mendapatkan pemaparan materi mengenai pemahaman akan hukum, pelangaran hukum, serta 
konsekuensi yang akan diterima akibat pelanggaran hukum. Lebih khusus, SMAS Yos Sudarso menghendaki agar diberikan pemahaman penyalahgunaan narkoba di kalangan remaja. Sehingga anak-anak SMAS Yos Sudarso di Batam ini bisa mengalami pertambahan wawasan pentingnya hukum dalam penerapannya di kehidupan sehari-hari.

Pasal 1 ayat (1) Undang-Undang Nomor 35 Tahun 2009 tentang Narkotika (UU Narkotika) menyatakan "narkotika adalah zat atau obat yang berasal dari tanaman atau bukan tanaman, baik sintetis maupun semi sintetis, yang dapat menyebabkan penurunan atau perubahan kesadaran, hilangnya rasa, mengurangi sampai menghilangkan rasa nyeri, dan dapat menimbulkan ketergantungan, yang dibedakan ke dalam golongan-golongan sebagaimana terlampir dalam Undang-Undang ini". Badan Narkotika Nasional Republik Indonesia memaparkan "dampak yang diberikan dengan mengonsumsi narkoba meliputi dehidrasi, halusinasi, menurunnya tingkat kesadaran, bahkan sampai kematian". Pentingnya penyuluhan hukum bagi siswa yaitu untuk memberikan pemahaman tentang hukum, tujuan hukum, mengapa hukum harus ditaati, konsekuensi atas pelanggaran hukum, penyalahgunaan narkotika dan sanksinya.

\section{METODE PELAKSANAAN PKM}

Tahapan pelaksanaan dari kegiatan Pengabdian Kepada Masyarakat yang dilakukan pada SMAS Katolik Yos Sudarso terdiri dari, pertama adalah adanya komunikasi antara pelaksana PKM dengan mitra. Komunikasi ini dilakukan secara online. Kedua adalah pengurusan perizinan kegiatan pelaksanaan pengabdian kepada masyarakat. Ketiga, menetapkan rencana jadwal pelaksanaan pengabdian kepada masyarakat. Keempat, menetapkan pembagian kerja antara mitra dengan pelaksana PKM. Kelima, menyusun proposal pengabdian kepada masyarakat. Keenam, mempersiapkan bahan dan peralatan yang dibutuhkan untuk keperluan pengabdian kepada masyarakat. Ketujuh merpakan hal yang dinantikan yakni melaksanakan kegiatan pengabdian kepada masyarakat. Kedelapan, membuat laporan luaran; Kesembilan, mengirim laporan akhir kegiatan pengabdian kepada masyarakat. Partisipasi mitra SMA Yos Sudarso dalam kegiatan Pengabdian Kepada Masyarakat antara lain: menyiapkan ruangan Zoom; menyusun waktu bersama pemateri; pemberian sertifikat kepada pemateri dan dokumentasi.

\section{HASIL DAN PEMBAHASAN}

Pelaksanaan kegiatan pengabdian kepada masyarakat dilakukan melalui virtual zoom meeting. Berikut adalah dokumentasi kegiatan pelaksanaan pengabdian kepada masyarakat di SMAS Yos Sudarso: 


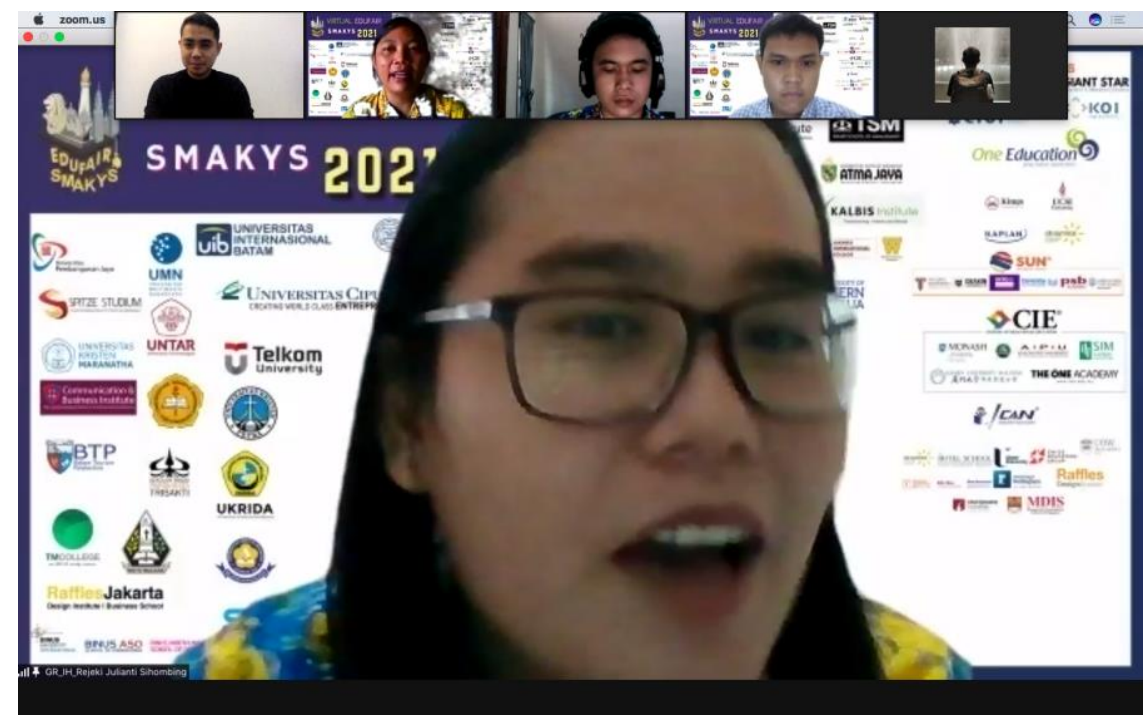

Gambar 1. Pelaksanaan PKM

Pada kegiatan pelaksanaan pengabdian kepada masyarakat ini, bentuk pelanggaran hukum yang dijelaskan adalah penyalahgunaan narkoba. Penyalahgunaan narkoba merupakan masalah hukum yang masih banyak terjadi di kalangan pelajar. Kegiatan pengabdian kepada masyarakat kali ini dapat dikatakan sebagai salah satu langkah untuk menanggulangi penyalahgunaan narkotika di kalangan remaja. Pemaparan materi yang disampaikan pada saat kegiatan antara lain:

a. Definisi Hukum

Pemahaman tentang hukum yang diberikan melalui pengabdian kepada masyarakat ini juga berguna untuk mengingatkan bahwa di mana ada masyarakat, maka di situ pula terdapat hukum (ubi societas ibi ius). Definisi tentang hukum diberikan pada kegiatan ini. Pelaksana menyampaikan bahwa hukum adalah pedoman perilaku manusia. Hukum sebagai sebuah pedoman yang harus dijalankan pada saat individu melakukan interaksi di keluarga atau masyarakat secara luas. Hukum dapat berbentuk tertulis dan tidak tertulis. hukum yang tertulis dapat dikemukakan antara lain berbagai aturan yang dibuat oleh negara yang dalam hal ini dapat berbentuk undang-undang, peraturan pemerintah, peraturan presiden dan lain sebagainya.

Secara substansial hukum mengatur perbuatan-perbuatan yang dilarang untuk dilakukan antara lain larangan membunuh, mencuri, berzina, menipu, menggelapkan, menggunakan narkotika dan lain sebagainya. Selain berisi larangan, hukum juga berisi aturan tentang perintah untuk melakukan perbuatan tertentu. Misalnya anak diperintahkan menghormati orang tua, siswa wajib menghormati guru dan lain sebagainya.

b. Tujuan Hukum

Materi berikutnya yang juga disampaikan pada saat pelaksanaan kegiatan pengabdian kepada masyarakat adalah berkenaan dengan tujuan hukum. Keberadaan hukum di masayarakat diperuntukan untuk mencapai berbagai tujuan. Tujuan tersebut beragam, antara lain mendatangkan keadilan, kemanfaatan, kepastian, ketertiban, kedamaian, kesejahteraan, perlindungan dan lain sebagainya. Dapat dibayangkan apabila hukum tidak dipatuhi atau diabaikan maka akan berdampak pada tidak dapat dicapainya berbagai tujuan hukum tersebut. Dalam kaitannya dengan remaja, maka ketaatan pada hukum oleh remaja dimaksudkan agar para siswa tetap berada dalam jalur menuju kesuksesan yang dicita-citakan.

c. Pelanggaran Hukum dan konsekuensinya

Pelaksana pengabdian menyampaikan bahwa pelanggaran hukum adalah perbuatan melakukan perbuatan yang dilarang atau tidak berbuat sesuatu yang diperintahkan oleh 
hukum. Berbicara mengenai pelanggaran hukum, pada prinsipnya pelanggaran hukum dapat terjadi pada berbagai lapangan bidang hukum, ada pelanggaran hukum perdata, administrasi, pidana dan lain sebagainya. Terdapat berbagai pelanggaran hukum yang ada, pelaksana pengabdian kepada masyarakat menekankan pada pelanggaran hukum yang terjadi dalam ranah hukum pidana. pelanggaran hukum dalam ranah hukum pidana terjadi pada saat seseorang melakukan perbuatan yang dilarang sebagaimana diatur dalam Kitab UndangUndang Hukum Pidana (KUHP) dan UU Narkotika. Terhadap semua perbuatan pelanggaran hukum akan berkonsekuensi pada pengenaan sanksi. Sanksi tersebut dapat berupa sanksi perdata, sanksi administrasi, sanksi pidana dan lain sebagainya.

Di dalam KUHP tindak pidana dikualifikasi menjadi 2 (dua) yakni Kejahatan dan Pelanggaran. Kejahatan diatur dalam Buku Ke-II dan Pelanggaran diatur dalam Buku Ke-III. Buku Ke-II yang mebgatur kejahatan di dalamnya terdapat Pasal 104 sampai dengan Pasal 488. Sedangkan di dalam Buku Ke-III tentang Pelanggaran di dalamnya terdapat Pasal 489 sampai dengan Pasal 569. Berbagai ketentuan pasal yang terdapat dalam kedua buku tersebut menjadi dasar untuk menjatuhkan pidana kepada pelaku tindak pidana.

d. Tindak pidana narkotika dan konsekuensinya

Pada kesempatan ini, bentuk pelanggaran hukum yang dikupas secara lengkap adalah penyalahgunaan narkotika. Penyalahgunana narkotika merujuk pada regulasi merupakan sebuah "tindak pidana (crime)". Berbagai perbuatan apa saja yang dikualifikasi sebagai tindak pidana narkotika dapat dilihat di dalam UU Narkotika. Di dalam undang-undang tersebut juga telah diatur berkenaan dengan sanksi apa yang dapat dikenakan apabila ada seseorang yang melakukan tindak pidana narkotika.

Lebih jauh dalam paparan pada saat pelaksanaan pengabdian, pelaksana menyampaikan bahwa dalam Pasal 4 UU Narkotika terdapat tujuan yang hendak diwujudkan meliputi: menjamin ketersediaan Narkotika untuk kepentingan pelayanan kesehatan dan/atau pengembangan ilmu pengetahuan dan teknologi; mencegah, melindungi, dan menyelamatkan bangsa Indonesia dari penyalahgunaan Narkotika; memberantas peredaran gelap Narkotika dan Prekursor Narkotika; dan menjamin pengaturan upaya rehabilitasi medis dan sosial bagi Penyalah Guna dan pecandu Narkotika. Pelanggaran terhadap UU Narkotika membuat berbagai tujuan tersebut menjadi sulit diwujudkan.

Dalam UU Narkotika terdapat berbagai tindak pidana yang dikualifikasi sebagai tindak pidana narkotika dan subjek hukum yang dapat dipertanggungjawabkan pidana. Berbagai perbuatan yang dikualifikasi sebagai tindak pidana narkotika diatur dalam Bab XV Ketentuan Pidana. beberapa perbuatan yang dikualifikasi sebagai tindak pidana narkotika antara lain: tanpa hak atau melawan hukum menanam, memelihara, memiliki, menyimpan, menguasai, atau menyediakan Narkotika Golongan I dalam bentuk tanaman (Pasal 111 ayat (1)); perbuatan menanam, memelihara, memiliki, menyimpan, menguasai, atau menyediakan Narkotika Golongan I dalam bentuk tanaman sebagaimana dimaksud pada ayat (1) beratnya melebihi 1 (satu) kilogram atau melebihi 5 (lima) batang pohon (Pasal 11 ayat (2)); tanpa hak atau melawan hukum memiliki, menyimpan, menguasai, atau menyediakan Narkotika Golongan I bukan tanaman (Pasal 119 ayat (1)); perbuatan memiliki, menyimpan, menguasai, atau menyediakan Narkotika Golongan I bukan tanaman beratnya melebihi 5 (lima) gram (Pasal 112 ayat (2)); tanpa hak atau melawan hukum memproduksi, mengimpor, mengekspor, atau menyalurkan Narkotika Golongan I (Pasal 113 ayat (1)); perbuatan memproduksi, mengimpor, mengekspor, atau menyalurkan Narkotika Golongan I dalam bentuk tanaman beratnya melebihi 1 (satu) kilogram atau melebihi 5 (lima) batang pohon atau dalam bentuk bukan tanaman beratnya melebihi 5 (lima) gram (Pasal 113 ayat (2); dan lain sebagainya. 
Dalam memahami kompleksitas pelanggaran hukum, para siswa selama ini hanya mendapatkan materi terbatas yang bersumber dari mata pelajaran kewarganegaraan, Sosiologi, PPKN dan lain sebagainya. Berbagai materi tentang ilmu hukum tentunya baru dapat didapatkan oleh para siswa ketika mengambil fakultas hukum setelah lulus. Pengabdian kepada masyarakat kali ini memberikan materi hukum yang secara spesifik membahas tentang pelanggaran hukum dan narkotika belum didapatkan. Oleh sebab itu, penyuluhan yang dilakukan sangatlah penting. Penyuluhan hukum yang telah dilakukan memberikan pemahaman tentang apa itu hukum, tujuan hukum, mengapa hukum harus ditaati, sanksi yang terdapat di dalam hukum, kebijakan penanggulangan narkotika dan lain sebagainya.

\section{KESIMPULAN}

Kegiatan pengabdian kepada masyarakat yang telah dilaksanakan memberikan peningkatan kesadaran hukum kepada para siswa seputar apa itu hukum, tujuan hukum, mengapa hukum harus ditaati, sanksi yang terdapat di dalam hukum, kebijakan penanggulangan narkotika dan lain sebagainya. Kegiatan seperti ini sebaiknya dilakukan secara rutin ke berbagai sekolah di seluruh Indonesia. Gunanya adalah meningkatkan kesadaran hukum seluruh siswa untuk tidak melakukan pelanggaran hukum.

\section{Ucapan Terima Kasih (Acknowledgement)}

Ucapan terima kasih kepada Lembaga Penelitian dan Pengabdian kepada Masyarakat (LPPM) Universitas Tarumanagara dan berbagai pihak yang telah membantu.

\section{REFERENSI}

Human, BNN. (2014). Selamatkan Remaja dari Pergaulan Bebas dan Narkoba. Diakses pada 21 September 2021. Diambil dari https://bnn.go.id/selamatkan-remaja-daripergaulan-bebas- dan-narkoba/

Humas, BNN. (2019). Pengertian Narkoba dan Bahaya Narkoba Bagi Kesehatan. Diakses pada 21 September 2021. Diambil dari https://bnn.go.id/pengertian-narkoba-danbahaya-narkoba- bagi-kesehatan/

Law, Justice. (2021). Begini Cara Menanamkan Kesadaran Hukum di Masyarakat. Diakses pada 21 September 2021. Diambil dari https://www.lawjustice.co/artikel/61689/begini-cara- menanamkan-kesadaran-hukum-dimasyarakat---/

Rachman, Fathur. (2017). Implementasi Penegakan Hukum Bagi Pengedar Narkotika di Indonesia Volume 12 No. 2. Diakses pada 21 September 2021. Diambil dari http://jurnalpranata.ubl.ac.id/index.php/pranatahukum/article/view/188

Silalahi, Dian. (2019). Sejarah SMAK Yos Sudarso. Diakses pada 21 September 2021. Diambil dari https://www.smakyossudarsobatam.sch.id/2019/10/sejarah-smak-yossudarso.html

Sari, Indah. (2019). Perbuatan Melawan Hukum dalam Hukum Pidana dan Hukum Perdata Volume 11 No. 1. Diakses pada 21 September 2021. Diambil dari https://journal.universitassuryadarma.ac.id/index.php/jihd/article/view/651

Santoso, L., Yahyanto. (2014). Pengantar Ilmu Hukum. Yogyakarta.

Wantu, Fence. (2015). Buku Ajar Pengantar Ilmu Hukum. Yogyakarta: Revivia Cendikia Humas, BNN. (2019). 4 Langkah Cara Mengatasi Kecanduan Narkoba. 
Seminar Nasional Hasil Penelitian dan Pengabdian Kepada Masyarakat 2021

Pengembangan Ekonomi Bangsa Melalui Inovasi Digital Hasil Penelitian dan

Pengabdian Kepada Masyarakat

Jakarta, 21 Oktober 2021

(halaman kosong) 